\title{
Possible use of repeated cold stress for reducing fatigue in Chronic Fatigue Syndrome: a hypothesis Nikolai A Shevchuk
} Address: Molecular Radiobiology Section, the Department of Radiation Oncology, Virginia Commonwealth University School of Medicine, 401
College St, Richmond, VA 23298, USA

Email: Nikolai A Shevchuk - nshevchuk@comcast.net

Published: 24 October 2007

Behavioral and Brain Functions 2007, 3:55 doi:10.1 186/1744-908I-3-55
Received: 5 July 2007

Accepted: 24 October 2007

This article is available from: http://www.behavioralandbrainfunctions.com/content/3/I/55

(c) 2007 Shevchuk; licensee BioMed Central Ltd.

This is an Open Access article distributed under the terms of the Creative Commons Attribution License (http://creativecommons.org/licenses/by/2.0), which permits unrestricted use, distribution, and reproduction in any medium, provided the original work is properly cited.

\begin{abstract}
Background: Physiological fatigue can be defined as a reduction in the force output and/or energygenerating capacity of skeletal muscle after exertion, which may manifest itself as an inability to continue exercise or usual activities at the same intensity. A typical example of a fatigue-related disorder is chronic fatigue syndrome (CFS), a disabling condition of unknown etiology and with uncertain therapeutic options. Recent advances in elucidating pathophysiology of this disorder revealed hypofunction of the hypothalamic-pituitary-adrenal axis and that fatigue in CFS patients appears to be associated with reduced motor neurotransmission in the central nervous system (CNS) and to a smaller extent with increased fatigability of skeletal muscle. There is also some limited evidence that CFS patients may have excessive serotonergic activity in the brain and low opioid tone.
\end{abstract}

Presentation of the hypothesis: This work hypothesizes that repeated cold stress may reduce fatigue in CFS because brief exposure to cold may transiently reverse some physiological changes associated with this illness. For example, exposure to cold can activate components of the reticular activating system such as raphe nuclei and locus ceruleus, which can result in activation of behavior and increased capacity of the CNS to recruit motoneurons. Cold stress has also been shown to reduce the level of serotonin in most regions of the brain (except brainstem), which would be consistent with reduced fatigue according to animal models of exercise-related fatigue. Finally, exposure to cold increases metabolic rate and transiently activates the hypothalamic-pituitaryadrenal axis as evidenced by a temporary increase in the plasma levels of adrenocorticotropic hormone, beta-endorphin and a modest increase in cortisol. The increased opioid tone and high metabolic rate could diminish fatigue by reducing muscle pain and accelerating recovery of fatigued muscle, respectively.

Testing the hypothesis: To test the hypothesis, a treatment is proposed that consists of adapted cold showers ( 20 degrees Celsius, 3 minutes, preceded by a 5 -minute gradual adaptation to make the procedure more comfortable) used twice daily.

Implications of the hypothesis: If testing supports the proposed hypothesis, this could advance our understanding of the mechanisms of fatigue in CFS. 


\section{Background}

There seems to be no universally accepted definition of biological fatigue [1], although it is often defined as a reduction in the force output and/or energy-generating capacity of skeletal muscle after exertion, which may manifest itself as an inability to continue exercise or usual activities at the same intensity [1-4]. Fatigue is thought to be associated with a diminished contractile ability of muscles due to accumulation of lactic acid and depletion of energy stores (glycogen) $[5,6]$ as well as with a reduction in motor neurotransmission delivered to skeletal muscle by the central nervous system (CNS), all of which can result in diminished force output $[7,8]$. At the level of the CNS, precise mechanisms of fatigue are not well understood, although there is some evidence that it may be associated with diminished activity of a brainstem structure called reticular activating system [9-11] and with increased levels of serotonin in the frontal cortex and hippocampus $[12,13]$.

A typical fatigue-related disorder is chronic fatigue syndrome (CFS), a complex and disabling condition characterized by extended periods of severe fatigue unexplained by known medical causes [14]. Currently, there are no specific diagnostic tests and etiology of CFS remains elusive, although some progress has been made in elucidating its pathophysiology $[15,16]$. A number of studies have reported insufficient function of the hypothalamic-pituitary-adrenal (HPA) axis (e.g. lowered production of cortisol $[16,17])$ and a rather frequent occurrence of autonomic nervous system dysfunction in patients with CFS $[16,18]$. Neither lowered production of cortisol nor dysautonomia appears to be a causative factor in most CFS patients because cortisol injections and various therapeutic approaches to autonomic nervous system abnormalities have so far shown a rather limited effect on CFS symptoms $[17,19,20]$. Other findings about the pathophysiology of CFS suggest that abnormal fatigability in this disorder is associated with a reduced ability of the CNS to recruit motor neurons [21-23] and with some biochemical abnormalities in skeletal muscle [24-26]. In addition, there is some evidence that CFS patients may have a low opioid tone ([27-30], contrary evidence: $[31,32])$, as well as an increased level of serotonergic activity in the brain ([33-38], contrary evidence: $[39,40])$. The latter has been shown to correlate with fatigue in animal models of exercise-related fatigue [13,41-45].

This paper describes a physiological treatment, namely, exposure to moderate cold, which could have a beneficial effect on some of the above-mentioned pathological changes as explained in more detail below.

\section{Presentation of the hypothesis}

It is known that small amounts of stressful or harmful agents can be beneficial for animals, a phenomenon known as hormesis $[46,47]$. In particular, exposure to cold can transiently reverse several physiological changes that are often associated with CFS and therefore, the hypothesis is that repeated cold stress can reduce fatigue in CFS patients. The following is detailed theoretical evidence that appears to support this hypothesis.

1) Insufficient function of the HPA axis has been found to correlate with fatigue [48], for example, a lowered plasma level of stress hormone cortisol (secreted by adrenal glands) is one of the few consistent endocrine changes found in CFS in numerous studies [17], although the level of cortisol in CFS patients is within the normal range and therefore cannot be used as a diagnostic tool [16]. Cold stress is known to transiently activate the HPA axis $[49,50]$ as evidenced by a brief increase in the plasma levels of adrenocorticotropic hormone $[51,52]$ and beta-endorphin (the latter is a secreted by the pituitary gland) $[53,54]$, as well as a modest elevation in the level of cortisol $[55,56]$. Some studies reported no significant change in cortisol levels following cold stress $[57,58]$, which may be due to gender and diurnal variation of this effect $[55,56]$. In addition, there is some evidence of another deficiency of the HPA axis in various disorders associated with fatigue: hypofunction of corticotropin-releasing hormone-producing neurons (located in hypothalamus) $[48,59,60]$. Therefore, "exercising" the HPA system by repeated exposure to cold could potentially restore its normal function in CFS, or at least increase the net HPA activity (without a change in baseline activity [61]) and, possibly, reduce fatigue. For example, repeated cold stress has been shown to enhance HPA axis responsiveness to other stressors $[62,63]$ and to enhance cortisol responses to cold stress [64].

2) Cold hydrotherapy is known to produce a significant analgesic effect [65-67], which could be beneficial in CFS, where pain symptoms are rather common $[68,69]$. The cold stress-induced analgesia is believed to be mediated by increased production of opioid peptide beta-endorphin, which is an endogenous pain-killer $[53,55,70,71]$.

3) Exposure to cold is known to increase metabolic rate: for instance, head-out immersion in cold water of $20^{\circ} \mathrm{C}$ almost doubles metabolic rate, while at $14^{\circ} \mathrm{C}$ it is more than quadrupled [72]. Theoretically, the high metabolic rate may accelerate $[73,74]$ the process of recovery of muscle tissues from fatigue in CFS [24,25,75,76] and some studies indeed show accelerated muscle recovery following immersion in cold water $[77,78]$. In combination with cold-induced analgesia described above, the increased metabolic rate would be expected to reduce fatigue by 
both improving muscle recovery after exertion and by reducing muscle pain [79]. A cold-induced increase in cerebral metabolic rate [80] may also be consistent with reduced fatigue $([7,81]$ contrary evidence: $[82,83])$.

4) There is evidence that exposure to cold can activate some components of the brainstem arousal system [8486] (also known as the reticular activating system $[87,88])$. In particular, cold stress appears to stimulate activity of serotonergic neurons of raphe nuclei $[84,89$ 91] and noradrenergic neurons of locus ceruleus [84,92], the situation that would be consistent with activation of behavior and enhanced somatomotor function of the brain $[9,87,93-96]$. This could be beneficial in CFS because abnormally high fatigability of CFS patients appears to be mediated by a reduction in the ability of the CNS to generate motor neurotransmission [21-23]. It is noteworthy that in polio survivors and patients with multiple sclerosis, the presence of minor lesions in the reticular activating system correlates with severe chronic fatigue $[10,97]$. This kind of lesions can also cause lethargy in laboratory animals $[9,88,98]$. Reduced electrical activity in the reticular activating system also appears to correlate with fatigue in laboratory animals [99-101]. At present, there is no evidence that CFS patients have lesions in the reticular activating system $[9,102]$, although there is some limited evidence of abnormalities of metabolism, blood flow, and electrical activity in the brainstem [81,103-105], the anatomical site of the reticular activating system $[87,88]$.

5) While the increased level of serotonin in the brainstem [85] is thought to correlate with arousal and increased cortical activity $[11,94,106]$, high levels of serotonin in other areas of the brain, particularly in the hippocampus and frontal cortex, are believed to be associated with fatigue, which is the basis of "the serotonin hypothesis of central fatigue" $[12,13,41-45]$. Whether high levels of brain serotonin actually cause fatigue or are merely an epiphenomenon is a subject of controversy $[12,13]$. With respect to cold stress, studies suggest that it reduces the level of serotonin in most regions of the brain $[107,108]$ except the rostral brainstem [85], which would be consistent with diminished fatigue $[12,13]$ and could be beneficial in CFS ([33-38], contrary evidence: $[39,40])$.

6) Exposure to cold typically causes activation of the sympathetic nervous system (SNS) $[49,109]$, which, theoretically, can be undesirable in CFS because there is evidence of hyperactivity of some components of the SNS in CFS patients $[18,110]$. It should be noted that physical exercise is also known to transiently activate the SNS [111] and graded exercise appears to be beneficial in CFS $[112,113]$. Therefore, brief cold stress will not necessarily have adverse effects on CFS patients (more detailed discussion can be found in Additional file 1).

7) As described previously, brief cold hydrotherapy appears to be safe and does not seem to have either shortterm or long-term adverse effects on health $[109,114$ 117]. The effect of moderately cold hydrotherapy (16$23^{\circ} \mathrm{C}$ ) on core body temperature is expected to be very small and therefore hypothermia is hardly a concern [118-120].

\section{Testing the hypothesis}

To test the hypothesis, a treatment is proposed that consists of adapted cold showers $\left(20^{\circ} \mathrm{C}, 3\right.$ minutes, preceded by 5 -minute gradual adaptation) twice a day. The detailed study protocol can be found in Additional file 2. Statistically insignificant preliminary evidence is described in Additional file 3.

\section{Implications of the hypothesis}

If statistically significant studies confirm (or refute) the hypothesis, this could further our understanding of the mechanisms of physiological fatigue and possibly contribute to the development of new therapeutic approaches to CFS.

\section{Competing interests}

The author(s) declare that they have no competing interests.

\section{Authors' contributions}

The idea and writing are solely N.A.S.'s.

\section{Additional material}

\section{Additional file 1}

Sympathetic nervous system and chronic fatigue syndrome. The file name is Additional_File_1.pdf and it contains a brief review of literature on the sympathetic nervous system abnormalities observed in patients with chronic fatigue syndrome. The file contains its own list of references separate from the main text.

Click here for file

[http://www.biomedcentral.com/content/supplementary/17449081-3-55-S1.pdf]

\section{Additional file 2}

Proposed study design. The file name is Additional_File_2.pdf and it contains a detailed protocol of the proposed study including statistical estimates of the sample size. The file contains its own list of references separate from the main text.

Click here for file

[http://www.biomedcentral.com/content/supplementary/17449081-3-55-S2.pdf] 


\section{Additional file 3}

Limited preliminary evidence. The file name is Additional_File_3.pdf and it provides a detailed description of preliminary evidence that appears to support the hypothesis. The file contains its own list of references separate from the main text.

Click here for file

[http://www.biomedcentral.com/content/supplementary/17449081-3-55-S3.pdf]

\section{Acknowledgements}

The author thanks Daniel Gebreselassie, Ph.D., for providing critical comments about the manuscript. Funding for this work was in part derived from the Children's National Medical Center/George Washington University Fellowship, Washington, DC, USA.

\section{References}

I. Weir JP, Beck TW, Cramer JT, Housh TJ: Is fatigue all in your head? A critical review of the central governor model. $\mathrm{Br} J$ Sports Med 2006, 40(7):573-86; discussion 586

2. Gandevia SC: Some central and peripheral factors affecting human motoneuronal output in neuromuscular fatigue. Sports Med 1992, I3(2):93-98.

3. Guessous I, Favrat B, Cornuz J, Verdon F: Fatigue: review and systematic approach to potential causes. Rev Med Suisse 2006, 2(89):2725-273।.

4. Evans WJ, Lambert CP: Physiological basis of fatigue. Am J Phys Med Rehabil 2007, 86(I Suppl):S29-46.

5. Schillings ML, Kalkman JS, Janssen HM, van Engelen BG, Bleijenberg G, Zwarts MJ: Experienced and physiological fatigue in neuromuscular disorders. Clin Neurophysiol 2007, I I 8(2):292-300.

6. Shulman RG, Rothman DL: The "glycogen shunt" in exercising muscle: A role for glycogen in muscle energetics and fatigue. Proc Natl Acad Sci U S A 200I, 98(2):457-46I.

7. Dalsgaard MK, Secher NH: The brain at work: A cerebral metabolic manifestation of central fatigue? J Neurosci Res 2007, 85(I5):3334-9.

8. Gandevia SC: Spinal and supraspinal factors in human muscle fatigue. Physiol Rev 200I, 8 I(4): I725-I 789.

9. Dickinson $\mathrm{CJ}$ : Chronic fatigue syndrome--aetiological aspects. Eur J Clin Invest 1997, 27(4):257-267.

10. Staub F, Bogousslavsky J: Fatigue after stroke: a major but neglected issue. Cerebrovasc Dis 200I, I 2(2):75-8I.

II. Sandyk R: Treatment with weak electromagnetic fields improves fatigue associated with multiple sclerosis. Int J Neurosci 1996, 84(I-4): I77-186.

12. Meeusen R, Watson P, Hasegawa H, Roelands B, Piacentini MF: Central fatigue: the serotonin hypothesis and beyond. Sports Med 2006, 36(I0):88I-909.

13. Blomstrand $\mathrm{E}$ : A role for branched-chain amino acids in reducing central fatigue. J Nutr 2006, I 36(2):544S-547S.

14. Chronic fatigue syndrome: basic facts Centers for Disease Control and Prevention, Atlanta, GA, USA [http://www.cdc.gov/cfs/cfsbasic facts.htm].

15. Cho HJ, Skowera A, Cleare A, Wessely S: Chronic fatigue syndrome: an update focusing on phenomenology and pathophysiology. Curr Opin Psychiatry 2006, 19(1):67-73.

16. Chronic fatigue syndrome: possible causes Centers for Disease Control and Prevention, Atlanta, GA, USA [http://www.cdc.gov/cfs/cfs causes.htm].

17. Cleare AJ: The neuroendocrinology of chronic fatigue syndrome. Endocr Rev 2003, 24(2):236-252.

18. Freeman $R$, Komaroff $A L$ : Does the chronic fatigue syndrome involve the autonomic nervous system? Am J Med 1997, 102(4):357-364.

19. Chronic fatigue syndrome: Treatment options Centers for Disease Control and Prevention, Atlanta, GA, USA [http://www.cdc.gov/cfs/ cfstreatmentHCP.htm].

20. Peterson PK, Pheley A, Schroeppel J, Schenck C, Marshall P, Kind A, Haugland JM, Lambrecht LJ, Swan S, Goldsmith S: A preliminary placebo-controlled crossover trial of fludrocortisone for chronic fatigue syndrome. Arch Intern Med 1998, I 58(8):908-9|4.

21. Schillings ML, Kalkman JS, van der Werf SP, van Engelen BG, Bleijenberg G, Zwarts MJ: Diminished central activation during maximal voluntary contraction in chronic fatigue syndrome. Clin Neurophysiol 2004, I I 5( I I):25 I 8-2524.

22. Siemionow V, Fang Y, Calabrese L, Sahgal V, Yue GH: Altered central nervous system signal during motor performance in chronic fatigue syndrome. Clin Neurophysiol 2004, I I5(10):2372-238I.

23. Kent-Braun JA, Sharma KR, Weiner MW, Massie B, Miller RG: Central basis of muscle fatigue in chronic fatigue syndrome. Neurology 1993, 43(I): |25-|3|.

24. Wong R, Lopaschuk G, Zhu G, Walker D, Catellier D, Burton D, Teo $\mathrm{K}$, Collins-Nakai R, Montague T: Skeletal muscle metabolism in the chronic fatigue syndrome. In vivo assessment by 3 IP nuclear magnetic resonance spectroscopy. Chest 1992, 102(6): $1716-1722$.

25. Jammes Y, Steinberg JG, Mambrini O, Bregeon F, Delliaux S: Chronic fatigue syndrome: assessment of increased oxidative stress and altered muscle excitability in response to incremental exercise. J Intern Med 2005, 257(3):299-310.

26. McCully KK, Smith S, Rajaei S, Leigh JS Jr., Natelson BH: Blood flow and muscle metabolism in chronic fatigue syndrome. Clin $\mathrm{Sci}$ (Lond) 2003, 104(6):64I-647.

27. Scott LV, Burnett F, Medbak S, Dinan TG: Naloxone-mediated activation of the hypothalamic-pituitary-adrenal axis in chronic fatigue syndrome. Psychol Med 1998, 28(2):285-293.

28. Conti F, Pittoni V, Sacerdote P, Priori R, Meroni PL, Valesini G: Decreased immunoreactive beta-endorphin in mononuclear leucocytes from patients with chronic fatigue syndrome. Clin Exp Rheumatol 1998, 16(6):729-732.

29. Panerai AE, Vecchiet J, Panzeri P, Meroni P, Scarone S, Pizzigallo E, Giamberardino MA, Sacerdote P: Peripheral blood mononuclear cell beta-endorphin concentration is decreased in chronic fatigue syndrome and fibromyalgia but not in depression: preliminary report. Clin J Pain 2002, 18(4):270-273.

30. Parker AJ, Wessely S, Cleare AJ: The neuroendocrinology of chronic fatigue syndrome and fibromyalgia. Psychol Med 200 I, 31(8): | $33 \mid-1345$.

31. Inder W], Prickett TC, Mulder RT: Normal opioid tone and hypothalamic-pituitary-adrenal axis function in chronic fatigue syndrome despite marked functional impairment. Clin Endocrinol (Oxf) 2005, 62(3):343-348.

32. Prieto J, Subira ML, Castilla A, Serrano M: Naloxone-reversible monocyte dysfunction in patients with chronic fatigue syndrome. Scand I Immunol 1989, 30(I): 13-20.

33. Cleare AJ, Bearn J, Allain T, McGregor A, Wessely S, Murray RM, O'Keane $\mathrm{V}$ : Contrasting neuroendocrine responses in depression and chronic fatigue syndrome. I Affect Disord 1995, 34(4):283-289.

34. Bakheit AM, Behan PO, Dinan TG, Gray CE, O'Keane V: Possible upregulation of hypothalamic 5-hydroxytryptamine receptors in patients with postviral fatigue syndrome. BMJ 1992 , 304(6833): $1010-1012$.

35. Sharpe M, Hawton K, Clements A, Cowen PJ: Increased brain serotonin function in men with chronic fatigue syndrome. BM] I997, 3 I 5(7| OI): |64-165.

36. Spath $M$, Welzel $D$, Farber $L$ : Treatment of chronic fatigue syndrome with 5-HT3 receptor antagonists--preliminary results. Scand J Rheumatol Suppl 2000, I I 3:72-77.

37. Badawy AA, Morgan CJ, Llewelyn MB, Albuquerque SR, Farmer A: Heterogeneity of serum tryptophan concentration and availability to the brain in patients with the chronic fatigue syndrome. J Psychopharmacol 2005, I 9(4):385-39I.

38. Georgiades E, Behan WM, Kilduff LP, Hadjicharalambous M, Mackie EE, Wilson J, Ward SA, Pitsiladis YP: Chronic fatigue syndrome: new evidence for a central fatigue disorder. Clin Sci (Lond) 2003, 105(2):2/3-2|8.

39. Yatham LN, Morehouse RL, Chisholm BT, Haase DA, MacDonald DD, Marrie TJ: Neuroendocrine assessment of serotonin (5HT) function in chronic fatigue syndrome. Can J Psychiatry 1995, 40(2):93-96.

40. Vassallo CM, Feldman E, Peto T, Castell L, Sharpley AL, Cowen PJ: Decreased tryptophan availability but normal post-synaptic 
5-HT2c receptor sensitivity in chronic fatigue syndrome. Psychol Med 200I, 3 I (4):585-59I.

41. Romanowski W, Grabiec S: The role of serotonin in the mechanism of central fatigue. Acta Physiol Pol 1974, 25(2): I27-134.

42. Soares DD, Coimbra CC, Marubayashi U: Tryptophan-induced central fatigue in exercising rats is related to serotonin content in preoptic area. Neurosci Lett 2007, 4I 5(3):274-278.

43. Fernstrom JD, Fernstrom MH: Exercise, serum free tryptophan, and central fatigue. J Nutr 2006, I 36(2):553S-559S.

44. Davis JM: Carbohydrates, branched-chain amino acids, and endurance: the central fatigue hypothesis. Int J Sport Nutr 1995, 5 Suppl:S29-38

45. Low D, Cable T, Purvis A: Exercise thermoregulation and hyperprolactinaemia. Ergonomics 2005, 48( I I- | - 4): I 547-I 557.

46. Arumugam TV, Gleichmann M, Tang SC, Mattson MP: Hormesis preconditioning mechanisms, the nervous system and aging. Ageing Res Rev 2006, 5(2): 165-178.

47. Leslie M: How can we use moderate stresses to fortify humans and slow aging? Sci Aging Knowledge Environ 2005, 2005(26):nf49.

48. Swain MG: Fatigue in chronic disease. Clin Sci (Lond) 2000, 99(I): $1-8$.

49. Nakamoto M: Responses of sympathetic nervous system to cold exposure in vibration syndrome subjects and agematched healthy controls. Int Arch Occup Environ Health 1990, 62(2): $177-181$.

50. Nakane T, Audhya T, Kanie N, Hollander CS: Evidence for a role of endogenous corticotropin-releasing factor in cold, ether, immobilization, and traumatic stress. Proc Natl Acad Sci U S A 1985, 82(4):|247-|25|.

5I. Ohno H, Yahata T, Yamashita K, Kuroshima A: Effect of acute cold exposure on ACTH and zinc concentrations in human plasma. Jpn J Physiol 1987, 37(4):749-755.

52. Goundasheva $D$, Andonova $M$, Ivanov V: Changes in some parameters of the immune response in rats after cold stress. Zentralbl Veterinarmed B 1994, 4 I ( I 0):670-674

53. Vaswani KK, Richard CW 3rd, Tejwani GA: Cold swim stressinduced changes in the levels of opioid peptides in the rat CNS and peripheral tissues. Pharmacol Biochem Behav 1988, 29(I): $163-168$.

54. Giagnoni G, Santagostino A, Senini R, Fumagalli P, Gori E: Cold stress in the rat induces parallel changes in plasma and pituitary levels of endorphin and ACTH. Pharmacol Res Commun 1983, I 5(I):|15-2I.

55. Gerra G, Volpi R, Delsignore R, Maninetti L, Caccavari R, Vourna S, Maestri D, Chiodera P, Ugolotti G, Coiro V: Sex-related responses of beta-endorphin, ACTH, GH and PRL to cold exposure in humans. Acta Endocrinol (Copenh) 1992, I 26 (I):24-28.

56. Smith DJ, Deuster PA, Ryan CJ, Doubt TJ: Prolonged whole body immersion in cold water: hormonal and metabolic changes. Undersea Biomed Res 1990, 17(2): 139-147.

57. Koska J, Ksinantova L, Sebokova E, Kvetnansky R, Klimes I, Chrousos $G$, Pacak K: Endocrine regulation of subcutaneous fat metabolism during cold exposure in humans. Ann N Y Acad Sci 2002, 967:500-505.

58. Marino F, Sockler JM, Fry JM: Thermoregulatory, metabolic and sympathoadrenal responses to repeated brief exposure to cold. Scand J Clin Lab Invest 1998, 58(7):537-545.

59. Gold PW, Licinio J, Wong ML, Chrousos GP: Corticotropin releasing hormone in the pathophysiology of melancholic and atypical depression and in the mechanism of action of antidepressant drugs. Ann N Y Acad Sci 1995, 771:716-729.

60. Neeck G, Crofford LJ: Neuroendocrine perturbations in fibromyalgia and chronic fatigue syndrome. Rheum Dis Clin North Am 2000, 26(4):989-1002

61. Dorfman M, Arancibia S, Fiedler JL, Lara HE: Chronic intermittent cold stress activates ovarian sympathetic nerves and modifies ovarian follicular development in the rat. Biol Reprod 2003, 68(6):2038-2043.

62. Pardon MC, Ma S, Morilak DA: Chronic cold stress sensitizes brain noradrenergic reactivity and noradrenergic facilitation of the HPA stress response in Wistar Kyoto rats. Brain Res 2003, 97 I(I):55-65

63. Ma S, Morilak DA: Chronic intermittent cold stress sensitises the hypothalamic-pituitary-adrenal response to a novel acute stress by enhancing noradrenergic influence in the rat paraventricular nucleus. J Neuroendocrinol 2005, I7(I I):76I-769.
64. Dugue B, Leppanen E: Adaptation related to cytokines in man: effects of regular swimming in ice-cold water. Clin Physiol 2000, 20(2): I| $4-|2|$.

65. Truesdell LS, Bodnar RJ: Reduction in cold-water swim analgesia following hypothalamic paraventricular nucleus lesions. Physiol Behav 1987, 39(6):727-731.

66. Kenunen OG, Prakh'e IV, Kozlovskii BL: A change in the alarm level entails a change in behavioural strategy of mice in stress and a change in analgesia induced by it. Ross Fiziol $\mathrm{Zh} \mathrm{Im}$ I M Sechenova 2004, 90( I 2): I555-I562.

67. LaFoy J, Geden EA: Postepisiotomy pain: warm versus cold sitz bath. I Obstet Gynecol Neonatal Nurs 1989, 1 8(5):399-403.

68. Fukuda K, Straus SE, Hickie I, Sharpe MC, Dobbins JG, Komaroff A: The chronic fatigue syndrome: a comprehensive approach to its definition and study. International Chronic Fatigue Syndrome Study Group. Ann Intern Med 1994, I 2 I (12):953-959.

69. Meeus M, Nijs J: Central sensitization: a biopsychosocial explanation for chronic widespread pain in patients with fibromyalgia and chronic fatigue syndrome. Clin Rheumatol 2007, 26(4):465-473.

70. Glickman-Weiss EL, Nelson AG, Hearon CM, Goss FL, Robertson RJ: Are beta-endorphins and thermoregulation during coldwater immersion related? Undersea Hyperb Med 1993 20(3):205-2I3

7I. Pickar D, Davis GC, Schulz SC, Extein I, Wagner R, Naber D, Gold PW, van Kammen DP, Goodwin FK, Wyatt RJ, Li CH, Bunney WE Jr.: Behavioral and biological effects of acute beta-endorphin injection in schizophrenic and depressed patients. Am J Psychiatry 198I, 138(2): 160-166.

72. Sramek P, Simeckova M, Jansky L, Savlikova J, Vybiral S: Human physiological responses to immersion into water of different temperatures. Eur J Appl Physiol 2000, 8 I (5):436-442.

73. St Rose JE, Murray GW, Howe SA: Effect of alterations in metabolic rate on the duration of tolerance in neonatally injected animals. Int Arch Allergy Appl Immunol 1976, 52(I-4): I83-187.

74. Vallerand AL, Zamecnik J, Jacobs I: Plasma glucose turnover during cold stress in humans. J Appl Physiol 1995, 78(4): 1296-1302.

75. McCully KK, Natelson BH: Impaired oxygen delivery to muscle in chronic fatigue syndrome. Clin Sci (Lond) 1999, 97(5):603-8; discussion 6II-3.

76. Fulle S, Mecocci P, Fano G, Vecchiet I, Vecchini A, Racciotti D, Cherubini A, Pizzigallo E, Vecchiet L, Senin U, Beal MF: Specific oxidative alterations in vastus lateralis muscle of patients with the diagnosis of chronic fatigue syndrome. Free Radic Biol Med 2000, 29(I 2): 1 252-1259.

77. Nomura T, Kawano F, Kang MS, Lee JH, Han EY, Kim CK, Sato Y, Ohira Y: Effects of long-term cold exposure on contractile muscles of rats. Jpn J Physiol 2002, 52(I):85-93.

78. Yanagisawa O, Niitsu M, Yoshioka H, Goto K, Kudo H, Itai Y: The use of magnetic resonance imaging to evaluate the effects of cooling on skeletal muscle after strenuous exercise. Eur J Appl Physiol 2003, 89(I):53-62.

79. Cook DB, Nagelkirk PR, Poluri A, Mores J, Natelson BH: The influence of aerobic fitness and fibromyalgia on cardiorespiratory and perceptual responses to exercise in patients with chronic fatigue syndrome. Arthritis Rheum 2006, 54(10):335I-3362

80. Szelenyi Z, Donhoffer Z: The effect of cold exposure on cerebral blood flow and cerebral available oxygen (aO2) in the rat and rabbit: thermoregulatory heat production by the brain and the possible role of neuroglia. Acta Physiol Acad Sci Hung 1978, 52(4):391-402.

8I. Tirelli U, Chierichetti F, Tavio M, Simonelli C, Bianchin G, Zanco P, Ferlin G: Brain positron emission tomography (PET) in chronic fatigue syndrome: preliminary data. Am J Med 1998, 105(3A):54S-58S.

82. Abu-Judeh $\mathrm{HH}$, Levine $\mathrm{S}$, Kumar $\mathrm{M}$, el-Zeftawy $\mathrm{H}$, Naddaf $\mathrm{S}$, Lou JO Abdel-Dayem HM: Comparison of SPET brain perfusion and I8F-FDG brain metabolism in patients with chronic fatigue syndrome. Nucl Med Commun 1998, 19(II): 1065-107I.

83. Siessmeier T, Nix WA, Hardt J, Schreckenberger M, Egle UT, Bartenstein P: Observer independent analysis of cerebral glucose metabolism in patients with chronic fatigue syndrome. J Neurol Neurosurg Psychiatry 2003, 74(7):922-928. 
84. Yuan L, Brewer C, Pfaff D: Immediate-early Fos protein levels in brainstem neurons of male and female gonadectomized mice subjected to cold exposure. Stress 2002, 5(4):285-294.

85. Passerin AM, Bellush LL, Henley WN: Activation of bulbospina serotonergic neurons during cold exposure. Can J Physiol Pharmacol 1999, 77(4):250-258.

86. Baffi JS, Palkovits M: Fine topography of brain areas activated by cold stress. A fos immunohistochemical study in rats. Neuroendocrinology 2000, 72(2): I02-II3.

87. Kayama $\mathrm{Y}$, Ito $\mathrm{S}$, Koyama $\mathrm{Y}$, Jodo $\mathrm{E}$ : Tonic and phasic components of the ascending reticular activating system. Fukushima J Med Sci 1991, 37(2):59-74.

88. Siegel J: Brain mechanisms that control sleep and waking. Naturwissenschaften 2004, 91 (8):355-365.

89. Dickenson $\mathrm{AH}$ : Specific responses of rat raphe neurones to skin temperature. J Physiol 1977, 273(I):277-293.

90. McAllen RM, Farrell M, Johnson JM, Trevaks D, Cole L, McKinley MJ, Jackson G, Denton DA, Egan GF: Human medullary responses to cooling and rewarming the skin: a functional MRI study. Proc Natl Acad Sci U S A 2006, I 03(3):809-8I3.

91. Ootsuka Y, Blessing WW: Inhibition of medullary raphe/parapyramidal neurons prevents cutaneous vasoconstriction elicited by alerting stimuli and by cold exposure in conscious rabbits. Brain Res 2005, I05 I (I-2): I89-193.

92. Jiang XH, Guo SY, Xu S, Yin QZ, Ohshita Y, Naitoh M, Horibe Y, Hisamitsu T: Sympathetic nervous system mediates cold stress-induced suppression of natural killer cytotoxicity in rats. Neurosci Lett 2004, 358( I): I-4

93. Stone EA, Lin Y, Ahsan R, Quartermain D: Role of locus coeruleus alpha I-adrenoceptors in motor activity in rats. Synapse 2004, 54(3): I64- I 72.

94. Lovick TA: The medullary raphe nuclei: a system for integration and gain control in autonomic and somatomotor responsiveness? Exp Physiol |997, 82(I):3 I-4I

95. Kiyashchenko LI, Mileykovskiy BY, Lai YY, Siegel JM: Increased and decreased muscle tone with orexin (hypocretin) microinjections in the locus coeruleus and pontine inhibitory area. Neurophysiol 2001, 85(5):2008-2016.

96. Hornung JP: The human raphe nuclei and the serotonergic system. J Chem Neuroanat 2003, 26(4):331-343.

97. Bruno RL, Cohen JM, Galski T, Frick NM: The neuroanatomy of post-polio fatigue. Arch Phys Med Rehabil 1994, 75(5):498-504.

98. Szymusiak R, Iriye T, McGinty D: Sleep-waking discharge of neurons in the posterior lateral hypothalamic area of cats. Brain Res Bull 1989, 23( I-2): I I I- I20.

99. Derevenco P, Stoica N, Sovrea I, Imreh S: Central and peripheral effects of 6-hydroxydopamine on exercise performance in rats. Psychoneuroendocrinology 1986, I I(2): |4|-I53.

100. Boev VM, Krauz VA: Functional state of the hippocampo-reticular complex during submaximal physical loading and fatigue. Zh Vyssh Nerv Deiat Im I P Pavlova I98I, 3 I (5):I029-I037.

I0I. Fornal CA, Martin-Cora FJ, Jacobs BL: "Fatigue" of medullary but not mesencephalic raphe serotonergic neurons during locomotion in cats. Brain Res 2006, I 072(I):55-6I.

102. Lewis DH, Mayberg HS, Fischer ME, Goldberg J, Ashton S, Graham MM, Buchwald D: Monozygotic twins discordant for chronic fatigue syndrome: regional cerebral blood flow SPECT. Radiology 2001, 21 9(3):766-773.

103. Neri G, Bianchedi M, Croce A, Moretti A: "Prolonged" decay test and auditory brainstem responses in the clinical diagnosis of the chronic fatigue syndrome. Acta Otorhinolaryngol Ital 1996, 16(4):317-323.

104. Bianchedi M, Croce A, Moretti A, Neri G, Barberio A, lezzi A, Pizzigallo $\mathrm{E}$ : Auditory brain stem evoked potentials in the evaluation of chronic fatigue syndrome. Acta Otorhinolaryngol ltal 1995 I 5(6):403-410.

105. Costa DC, Tannock C, Brostoff J: Brainstem perfusion is impaired in chronic fatigue syndrome. QJM 1995, 88( I I ):767-773.

I06. O'Leary OF, Bechtholt AJ, Crowley J], Valentino RJ, Lucki I: The role of noradrenergic tone in the dorsal raphe nucleus of the mouse in the acute behavioral effects of antidepressant drugs. Eur Neuropsychopharmacol 2007, I 7(3):2I 5-226.

107. Aly MS, Mohamed MI, Rahman TA, Moustafa S: Studies of contents of norepinephrine and 5-hydroxytryptamine in brain--I. Nor- mal and cold exposure. Comp Biochem Physiol C 1985 82(I): $155-158$

108. Toh CC: Effects of temperature on the 5-hydroxytryptamine (serotonin) content of tissues. I Physiol I960, I 5 I:4 I0-4I5.

109. Jansky L, Sramek P, Savlikova J, Ulicny B, Janakova H, Horky K: Change in sympathetic activity, cardiovascular functions and plasma hormone concentrations due to cold water immersion in men. Eur J Appl Physiol Occup Physiol I996, 74( I-2): | 48-I 52.

I 10. Wyller VB, Godang K, Morkrid L, Saul JP, Thaulow E, Walloe L: Abnormal thermoregulatory responses in adolescents with chronic fatigue syndrome: relation to clinical symptoms. Pediatrics 2007, I 20(I):e I29-37.

III. Toth MJ, Gardner AW, Arciero PJ, Calles-Escandon J, Poehlman ET: Gender differences in fat oxidation and sympathetic nervous system activity at rest and during submaximal exercise in older individuals. Clin Sci (Lond) 1998, 95( I):59-66.

I 12. Moss-Morris R, Sharon C, Tobin R, Baldi JC: A randomized controlled graded exercise trial for chronic fatigue syndrome: outcomes and mechanisms of change. J Health Psychol 2005, I 0(2):245-259.

I 13. Wallman KE, Morton AR, Goodman C, Grove R, Guilfoyle AM: Randomised controlled trial of graded exercise in chronic fatigue syndrome. Med J Aust 2004, I 80(9):444-448.

I 14. Holloszy JO, Smith EK: Longevity of cold-exposed rats: a reevaluation of the "rate-of-living theory". I Appl Physiol 1986, 6 I(5): | 656-1660.

I I5. Jansky L, Pospisilova D, Honzova S, Ulicny B, Sramek P, Zeman V, Kaminkova J: Immune system of cold-exposed and coldadapted humans. Eur J Appl Physiol Occup Physiol 1996, 72(56):445-450

I 16. Castellani JW, IK MB, Rhind SG: Cold exposure: human immune responses and intracellular cytokine expression. Med $\mathrm{Sci}$ Sports Exerc 2002, 34( I 2):2013-2020.

I 17. Baneriee SK, Aviles H, Fox MT, Monroy FP: Cold stress-induced modulation of cell immunity during acute Toxoplasma gondii infection in mice. J Parasitol 1999, 85(3):442-447.

I 18. Doufas AG, Sessler DI: Physiology and clinical relevance of induced hypothermia. Neurocrit Care 2004, I(4):489-498.

II9. Tikuisis P: Heat balance precedes stabilization of body temperatures during cold water immersion. J Appl Physiol 2003 95(I):89-96.

120. McCullough L, Arora S: Diagnosis and treatment of hypothermia. Am Fam Physician 2004, 70( $122325-2332$ [http://www.aafp.org/ afp/2004/2/5/2325.html].

Publish with Biomed Central and every scientist can read your work free of charge

"BioMed Central will be the most significant development for disseminating the results of biomedical research in our lifetime. "

Sir Paul Nurse, Cancer Research UK

Your research papers will be:

- available free of charge to the entire biomedical community

- peer reviewed and published immediately upon acceptance

- cited in PubMed and archived on PubMed Central

- yours - you keep the copyright
BiolMedcentral 